Dept. Food Hygiene,

Fac. Vet. Med., Alex. Univ., Egypt

\title{
QUALITY EVALUATION OF CONCENTRATED MILKS SOLD AT LOCAL MARKETS
}

(With 5 Tables)

\author{
By

\section{A.M. NAZEM; A.A. AMER; Y.S. ABD ELSHAHID* \\ and SALLY ASHREY*}

*Animal Health Research Institute (Alexandria branch), Egypt.

(Received at 15/3/2011)

\section{تقييم جودة الألبان المركزة المباعة فى الأسواق المحلية}

اشرف ناظم ، عمرو عامر ، بوسف عبد الشهيل ، سالى عشرى

ان الالبان المركزة المحلاة و غير المحلاة موجودة فى الاسواق المحلية تحت مسميات تجارية

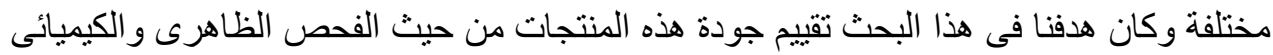

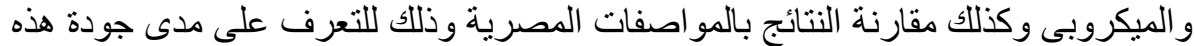

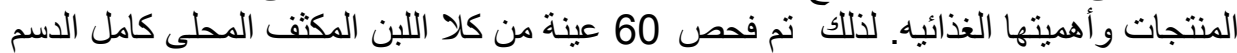

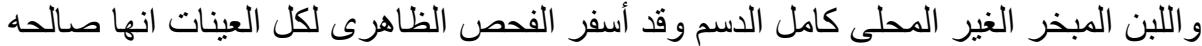

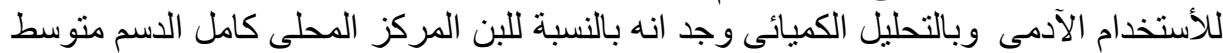

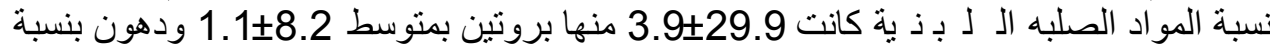

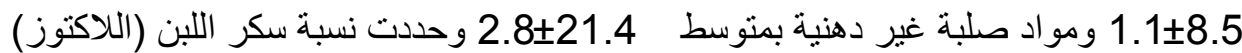

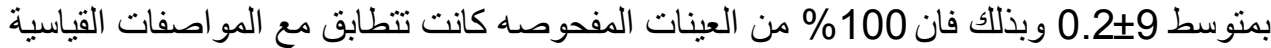

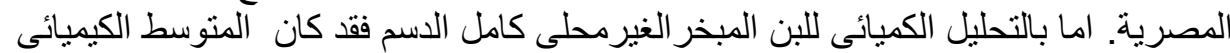

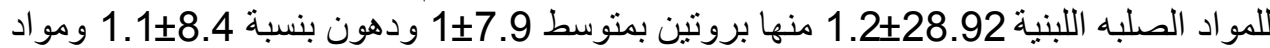

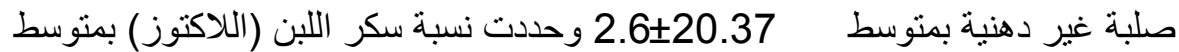

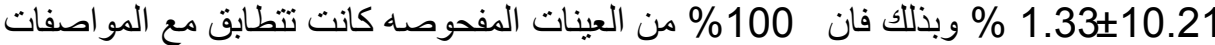

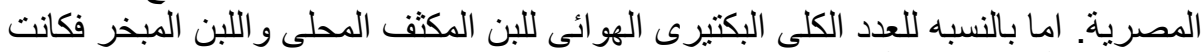

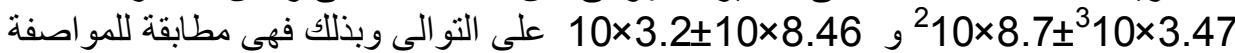

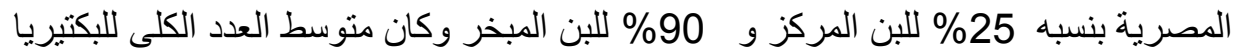

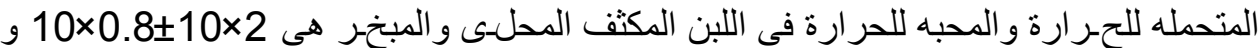

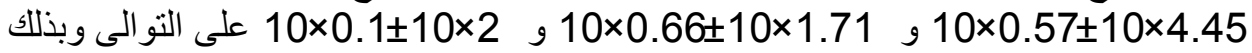

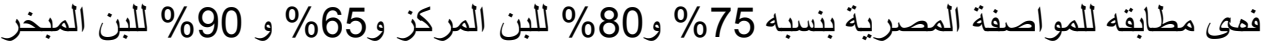

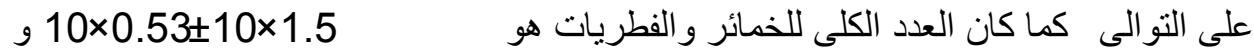

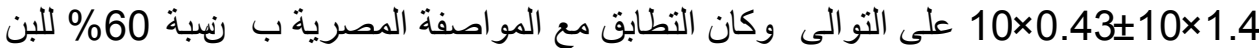

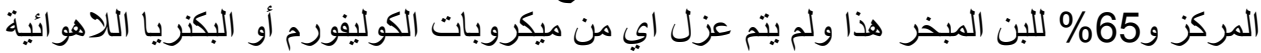

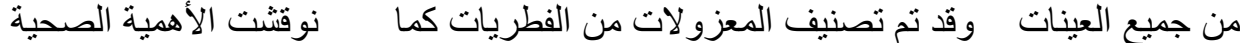

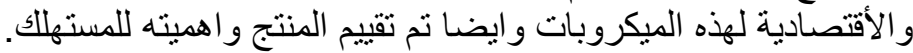




\section{SUMMARY}

Concentrated milk is an important dairy product, because it can be utilized as a final product or as intermediate material. One hundred and twenty random samples of concentrated milk (60 each of full cream sweetened condensed and unsweetened evaporated milks) of different brands were collected from supermarkets in Alexandria Governorate for sensory, chemical and microbiological evaluations. The mean values of total milk solids, protein, solid not fat, fat and lactose contents in the examined full cream sweetened condensed milk samples were $29.9 \pm 3.9,8.2 \pm 1.1,21.4$ $\pm 2.8,8.5 \pm 1.1$ and $9.0 \pm 0.2$, respectively. Meanwhile, the corresponding mean values of total milk solids, protein, solid not fat, fat and lactose contents in examined full cream unsweetened evaporated milk samples were $28.92 \pm 3.7,7.9 \pm 1,20.37 \pm 2.6,8.4 \pm 1.1$ and $10.21 \pm 1.33$. The mean values of aerobic plate count, thermoduric bacterial count, thermophilic bacterial count and total yeast and mould count in the examined full cream sweetened condensed milk samples were $3.47 \times 10^{3} \pm 8.7 \times 10^{2} ; 2 \times 10 \pm 0.87 \times 10 ; 4.45 \times 10 \pm 0.5 \times 10$ and $1.5 \times 10 \pm$ $0.53 \times 10$, respectively. Meanwhile in full cream unsweetened evaporated milk, the mean values of the concerning microorganisms were $8.46 \times 10 \pm$ $3.2 \times 10 ; 1.71 \times 10 \pm 0.66 \times 10 ; 2 \times 10 \pm 0.1 \times 10$ and $1.4 \times 10 \pm 0.43 \times 10$, respectively. Coliforms and anaerobic bacteria could not be detected in the examined samples of both concentrated milk types. The public health, economic importance of the isolated species and suggested control measures were discussed.

Key words: Concentrated milk, sensory, chemical, microbiological, evaluation

\section{INTRODUCTION}

In the early days in most countries, concentrated milk types were sold in such the same manner as liquid milk, because of their high milk solids, extended shelf life and considerable cost saving which obtained by transporting of the concentrates due to its reduced volume and weight (Hui, 1993).

Sweetened condensed milk is a nourishing, delicious, easily digestible and good source of energy. It is designed for use in the retail market in a variety of applications such as cooked and uncooked desserts, salad dressings and beverages as a topping for fruits or ice cream. Condensed milks can also be used undiluted in coffee and tea. Most condensed whole milk is used as an ingredient in chocolate/confectionery, or dairy industries (frozen dessert); while condensed skim milk is not 
subsequently dried but it is used primarily within the dairy industry (ADPI, 2000).

Keeping quality of evaporated milk depends on the efficiency of sterilization of the final product and on the prevention of post-heat contamination while in condensed milks it depends primarily on concentration of added sucrose or other sugars and to some extent on the concentration of milk solids (NDPRC, 2009). The plasmolyzing action of the materials of solution prevents the growth of organisms (Robinson, 2002).

Microbiological evaluation of evaporated milk by customary procedures immediately after packaging will usually reveal no viable organisms, and microorganisms seldom develop even after prolonged holding at room temperature (Clark, 2000). In past years, much canned evaporated milk was held for 2-3 weeks in a warm room to detect spoilage before shipping; but, with improved technology and laboratory control, holding of the entire lot is seldom done (Robinson, 2002).

A general risk due to post-processing contamination, of course, exist with non-sterile products, while sterilized concentrated milk is subjected to the same risks as all canned foods with respect to under processing and seam leakage (Varnam and Sutherland, 1994). Several outbreaks of acute gastrointestinal disturbance have been reported due to consumption of condensed milk (Cockburan and Vernon, 1956). Apergillus, Penicillium, Coliforms and spore formers may associate with defects in condensed milk, especially if the canned products are held for longer time (Robinson, 2002).

Both sweetened condensed and evaporated milks are extensively imported from different countries abroad. They are intended for sale in markets under various commercial names therefore, this work was planned to evaluate the quality of concentrated milk retailed in Alexandria Governorate.

\section{MATERIALS and METHODS}

\section{Sampling:}

One hundred and twenty random samples of full cream concentrated milk samples, comprises 60 samples each of unsweetened evaporated and sweetened condensed milk, were collected from different supermarkets in Alexandria Governorate. Samples were directly transferred, with a minimum of delay, to the laboratory of Animal Health Research Institute, Alexandria branch where they subjected for sensory, chemical and microbiological examinations. 


\section{Sensory evaluation (Clark et al., 2009).}

3. Chemical evaluation: - (Milk content analyser, Lactostar, No. 3510)

\section{Microbiological evaluation:-}

4.1. Preparation of serial dilutions (APHA, 1992).

4.2. Aerobic plate count (APC) (APHA, 1992).

4.3. Thermoduric count (APHA, 1992).

4.4. Thermophilic count (APHA, 1992).

4.5. Coliforms count (MPN) (AOAC, 1994).

4.6. Total Yeasts and Moulds Count (Bailey and Scott, 1998).

4.7. Identification of moulds:- Raper and Fennel (1965) and Samson et al. (1995) for genus Aspergillus, Samson et al. (1995) for genus Penicillium, while other genera were identified according to Zycha et al. (1969); Barnnett and Hunter (1972) and Samson et al. (1995).

4.8. Detection of Anaerobic Spore formers by using Stormy Fermentation test according to (Cruickshank et al., 1975).

\section{RESULTS}

Table 1: Statistical analytical results of Sensory evaluation of full cream sweetened condensed and full cream unsweetened evaporated milk samples against standard requirements $(n=60$ for each) (Clark, 2000):

\begin{tabular}{|c|c|c|c|c|}
\hline \multirow{2}{*}{ Criteria } & \multicolumn{2}{|c|}{$\begin{array}{c}\text { Sweetened condensed milk samples } \\
\text { not comply with standard } \\
\text { requirements }\end{array}$} & \multicolumn{2}{|c|}{$\begin{array}{c}\text { Unsweetened evaporated milk } \\
\text { samples not comply with standard } \\
\text { requirements }\end{array}$} \\
\hline & $\begin{array}{c}\text { No. } \\
\text { (Characterization of defects) }\end{array}$ & $\%$ & $\begin{array}{c}\text { No. } \\
\text { (Characterization of defects) }\end{array}$ & $\%$ \\
\hline $\begin{array}{l}\text { Appearance of } \\
\text { the container }\end{array}$ & $\begin{array}{c}8 \\
\text { (Rust and bad cans) }\end{array}$ & 13 & $\begin{array}{c}6 \\
\text { (Rust and bad cans) }\end{array}$ & 10 \\
\hline $\begin{array}{l}\text { Color and } \\
\text { Luster }\end{array}$ & $\begin{array}{c}10 \\
\text { (Dark golden with luster) }\end{array}$ & 17 & 0 & 0 \\
\hline Taste and smell & $\begin{array}{c}10 \\
\text { (Too sweet unpleasant taste) }\end{array}$ & 17 & 0 & 0 \\
\hline $\begin{array}{l}\text { Texture, } \\
\text { Viscosity and } \\
\text { Sediment }\end{array}$ & $\begin{array}{c}10 \\
\text { (more viscous with no sediment) }\end{array}$ & 17 & 0 & 0 \\
\hline $\begin{array}{l}\text { Feathering in } \\
\text { coffee }\end{array}$ & - & - & $\begin{array}{c}3 \\
\text { (Make oil drops on coffee } \\
\text { surface) }\end{array}$ & $5 \%$ \\
\hline
\end{tabular}


Table 2: Statistical analytical results of Chemical composition of full cream sweetened condensed and unsweetened evaporated milk samples against Egyptian Standards (ES, part 1and 2, 2005) $(n=60$ for each)

\begin{tabular}{|l|c|c|c|c|c|c|}
\hline \multirow{2}{*}{ Criteria } & \multicolumn{3}{|c|}{ Sweetened condensed milk } & \multicolumn{3}{c|}{ Unsweetened evaporated milk } \\
\cline { 2 - 7 } & Min - Max & Mean \pm SEM & ES & Min - Max & Mean \pm SEM & ES \\
\hline TMS \% & $28.59-31.25$ & $29.9 \pm 3.9$ & 28 & $28.52-29.14$ & $28.92 \pm 1.2$ & 25 \\
\hline Protein \% & $7.63-8.8$ & $8.2 \pm 1.1$ & & $7.60-8.17$ & $7.9 \pm 1$ & \\
\hline SNF \% & $20.36-22.46$ & $21.4 \pm 2.8$ & 20 & $20.25-20.52$ & $20.37 \pm 2.6$ & 17 \\
\hline Fat \% & $8.23-8.79$ & $8.5 \pm 1.1$ & 8 & $8.19-8.62$ & $8.4 \pm 1.1$ & 7.5 \\
\hline Lactose \% & $8.43-9.44$ & $9.0 \pm 0.2$ & & $8.43-11.98$ & $10.21 \pm 1.33$ & \\
\hline
\end{tabular}

TMS $=$ Total Milk Solids, SNF $=$ Solid Not Fat, Min = Minimum, Max = Maximum, SEM = Standard Error of Mean, ES. = Egyptian Standards.

Table 3: Microbiological evaluation of full cream sweetened condensed milk samples compared with Egyptian Standards $(\mathrm{ES}$, part 2,2005) $(\mathrm{n}=60)$.

\begin{tabular}{|l|c|c|c|c|c|c|c|}
\hline \multirow{2}{*}{ Criteria } & \multicolumn{2}{|c|}{$\begin{array}{c}\text { Positive } \\
\text { samples }\end{array}$} & Min - Max & Mean \pm SEM & \multirow{2}{*}{ ES } & \multicolumn{2}{c|}{$\begin{array}{c}\text { Samples not } \\
\text { complied } \\
\text { with ES }\end{array}$} \\
\cline { 2 - 6 } & No. & $\%$ & & & & No. & $\%$ \\
\hline $\begin{array}{l}\text { Aerobic Plate } \\
\text { Count }\end{array}$ & 49 & 81.7 & $5 \times 10-1.1 \times 10^{4}$ & $3.47 \times 10^{3} \pm 8.7 \times 10^{2}$ & $\leq 100$ & 45 & 75 \\
\hline $\begin{array}{l}\text { Coliforms } \\
\text { count (MPN) }\end{array}$ & 0 & 0 & $0-0$ & 0 & 0 & 0 & 0 \\
\hline $\begin{array}{l}\text { Thermoduric } \\
\text { bacterial count }\end{array}$ & 15 & 25 & $1 \times 10-3 \times 10$ & $2 \times 10 \pm 0.87 \times 10$ & 0 & 15 & 25 \\
\hline $\begin{array}{l}\text { Thermophilic } \\
\text { bacterial count }\end{array}$ & 12 & 20 & $2 \times 10-6 \times 10$ & $4.45 \times 10 \pm 0.57 \times 10$ & 0 & 12 & 20 \\
\hline $\begin{array}{l}\text { Total Yeast } \\
\text { and Mould } \\
\text { count }\end{array}$ & 24 & 40 & $1 \times 10-3 \times 10$ & $1.5 \times 10 \pm 0.53 \times 10$ & 0 & 24 & 40 \\
\hline $\begin{array}{l}\text { Detection of } \\
\text { Anaerobic } \\
\text { bacteria (SFT) }\end{array}$ & 0 & 0 & $0-0$ & 0 & 0 & 0 & 0 \\
\hline
\end{tabular}


Table 4: Microbiological criteria/ $\mathrm{ml}$ of full cream unsweetened evaporated milk samples compared with Egyptian Standards $(E S$, part 1,2005$)(n=60)$.

\begin{tabular}{|l|c|c|c|c|c|c|c|}
\hline \multirow{2}{*}{ Criteria } & \multicolumn{2}{|c|}{$\begin{array}{c}\text { Positive } \\
\text { samples }\end{array}$} & Min - Max & Mean \pm SEM & ES & \multicolumn{2}{c|}{$\begin{array}{c}\text { Samples not } \\
\text { complied with ES }\end{array}$} \\
\cline { 2 - 8 } & No. & $\%$ & & & No. & $\%$ \\
\hline $\begin{array}{l}\text { Aerobic Plate } \\
\text { count }\end{array}$ & 24 & 40 & $1 \times 10-1.73 \times 10^{3}$ & $8.46 \times 10 \pm 3.2 \times 10$ & $\leq 100$ & 6 & 10 \\
\hline $\begin{array}{l}\text { Coliforms count } \\
\text { (MPN) }\end{array}$ & 0 & 0 & $0-0$ & 0 & 0 & 0 & 0 \\
\hline $\begin{array}{l}\text { Thermoduric } \\
\text { bacterial count }\end{array}$ & 21 & 35 & $1 \times 10-3 \times 10$ & $1.71 \times 10 \pm 0.66 \times 10$ & 0 & 21 & 35 \\
\hline $\begin{array}{l}\text { Thermophilic } \\
\text { bacterial count }\end{array}$ & 6 & 10 & $1 \times 10-2.4 \times 10$ & $2 \times 10 \pm 0.1 \times 10$ & 0 & 6 & 10 \\
\hline $\begin{array}{l}\text { Total Yeast and } \\
\text { Mould count }\end{array}$ & 21 & 35 & $1.16 \times 10-2 \times 10$ & $1.4 \times 10 \pm 0.43 \times 10$ & 0 & 21 & 35 \\
\hline $\begin{array}{l}\text { Detection of } \\
\text { Anaerobic } \\
\text { bacteria (SFT) }\end{array}$ & 0 & 0 & $0-0$ & 0 & 0 & 0 & 0 \\
\hline
\end{tabular}

Table 5: Frequency distribution of the identified mould species isolated from the examined full cream sweetened condensed and unsweetened evaporated milk samples ( $n=60$ for each).

\begin{tabular}{|l|c|c|c|c|}
\hline \multirow{2}{*}{ Isolated mould species } & \multicolumn{2}{|c|}{ Sweetened condensed milk } & \multicolumn{2}{c|}{ Unsweetened evaporated milk } \\
\cline { 2 - 5 } & Frequency & $\%$ & Frequency & $\%$ \\
\hline Alternaria alternaria & 3 & 5.00 & 2 & 3.30 \\
Aspergillus flavus & 5 & 8.33 & 4 & 6.67 \\
Aspergillus fumigates & 3 & 5.00 & 2 & 3.30 \\
Aspergillus niger & 4 & 6.67 & 6 & 10.00 \\
Aspergillus terreus & 5 & 8.33 & 4 & 6.67 \\
Penicillium spp. & 4 & 6.67 & 3 & 5.00 \\
\hline Total & 24 & 40 & 21 & 34.94 \\
\hline
\end{tabular}




\section{DISCUSSION}

\section{Sensory evaluation}

All samples were examined before opened (closed cans examination), and after opening for surface appearance, luster, texture, color, viscosity, sediment, flavor and the product reaction to hot drinks. They all were normal with no abnormalities, except some uniformity, rusts, and impropriate appearance of some cans (Table, 1). The labeling requirements were carried out according to the regulations in FDA (2006). None of the samples has deformities that render it unfit for human consumption.

The body characteristics of concentrated milks have been markedly improved through the use of stabilizers that prevent physical separation during storage and help the product to be smooth and creamy throughout typical distribution cycles (Garcia, 1959).

Data recorded in Table (1) showed that ten samples of sweetened condensed milk were not complying with these requirements (color, luster, taste, smell, texture or viscosity), they all were from one brand and it was somewhat different from the other tested brands just in sensory parameters neither chemical nor microbiological.

\section{Chemical examination:}

Generally the total solids content of a product is a key parameter in food industry. It can be part of the determination of the final product composition. The water content of a product is often regulated by legislation and might strongly influence the product's stability. During food processing, the total solids content often affects final product quality (Davis, 1970). All evaporated milks and most sweetened condensed, milk products are manufactured using raw milk grade (A) (USPHS, 1997).

Results registered in Table (2) revealed that all samples of full cream sweetened condensed milk were complied with the Egyptian Standards, part2 (2005) in both total milk solids which must not be less than $28 \%$ and fat requirement not less than $8 \%$. As well all full cream unsweetened evaporated milk samples were complied with the Egyptian Standards, part 1 (2005) in both total milk solids and fat \% which are not less than 25 and $7.5 \%$, respectively.

As full cream sweetened condensed milk is preserved by addition of sugar, consequently its water activity is reduced to a point inhibit the growth of most microorganisms. Also, the increased milk solids content decreases the water activity. 


\section{Microbiological evaluation of concentrated milk samples:-}

Dairy products have generally been considered an excellent source of high-quality protein, calcium, potassium, phosphorus, magnesium, zinc, and the B-vitamins riboflavin, niacin, vitamin B-6, and vitamin B-12 Buttriss (1997). Not only but they are also an excellent media for most microbial organisms.

Table (3) showed that the mean value of aerobic plate count in the examined sweetened condensed milk was $3.47 \times 10^{3} \pm 8.7 \times 10^{2} \mathrm{cfu} / \mathrm{g}$. According to the standard specified by APHA (1992), the total bacterial count /g of sweetened condensed milk should not exceed 500/g, so $25 \%$ of examined samples do not comply with such standard, while $75 \%$ of the examined samples don't comply with the ES, part2 (2005) which require less than 100 cell/g of milk. However, Sallam (1979) and Ahmed et al. (1988), reported higher results. In Table (4) the mean value of aerobic plate count in the examined evaporated milk samples was $8.46 \times 10 \pm 3.2 \times 10 \mathrm{cfu} / \mathrm{g}$, only $10 \%$ of the examined samples were not complied with the ES.part1 (2005).

However, Arora (1987) and Robinson (1990) recorded different ranges during their works on the same product. They found that the viable counts ranged between few hundred to $10^{4} \mathrm{cfu} / \mathrm{g}$, while the mean of tested samples of sweetened condensed milk was $8.46 \times 10 \pm 3.2 \times 10 \mathrm{cfu} / \mathrm{g}$ with a range between 50:11.000 cfu/g.

Many authors recommended the aerobic plate count as an index of hygienic measure, organoleptic quality, safety and utility of the product. It reflects the microbial content of raw materials and effectiveness of manufacture techniques and sanitary care of equipment and utensils (Adams and Moss, 2000).

The main source of contamination of condensed milk by microorganisms may be from imperfectly cleaned machinery and incompletely sterilized tins (Garcia, 1959).

In Tables (3) thermoduric bacterial count and thermophilic bacterial count were found in a mean of $2 \times 10 \pm 0.87 \times 10$ and $4.45 \times 10 \pm 0.57 \times 10$ cfu/g for full cream sweetened condensed milk samples which complied with the ES (part 2, 2005) in percentages $75 \%$ and $80 \%$ consequently. Meanwhile in Table (4) they were $1.71 \times 10 \pm 0.66 \times 10$ and $1.5 \times 10 \pm$ $0.19 \times 10 \mathrm{cfu} / \mathrm{g}$ of full cream unsweetened evaporated milk samples were complied with ES (part 1, 2005) in percentages of 65 and 90\% respectively.

Spore-forming bacteria present in raw milk are destroyed by exposure to time and temperature combinations currently used for milk pasteurization, but full cream sweetened condensed milk is not a sterile 
product and the various methods of heat treatment used are not adequate to kill spore forming bacteria, and further processing and handling usually contribute variety of microorganisms. Here comes the rule of sugar concentration which reached up to $45 \%$ in preserving sweetened condensed milk by reducing water activity to a point inhibit most microorganisms.

Full cream unsweetened evaporated milk is commercially sterile, and must be free from all microorganisms of public health significance and must not show microbial defects during its intended shelf life under normal conditions of handling, storage and distribution (Robinson, 2002; NDPRC, 2009).

As in its manufacture milk is quickly heated in one of two ways. The High Temperature Short Time method (HTST) subjects milk to temperature of $161{ }^{\circ} \mathrm{F}\left(71.6^{\circ} \mathrm{C}\right)$ for 15 seconds. The Ultra High Temperature (UHT) method heats the milk to $280^{\circ} \mathrm{F}\left(138^{\circ} \mathrm{C}\right)$ for two seconds and both methods increase the milk's stability, decrease the chance of coagulation during storage, and decrease the bacterial level (Curran and Evans, 1945).

But high viable count often indicates contamination of raw material, unsatisfactory sanitation or unsuitable time and temperature conditions during storage and/or production specially during cooling and filling process in sweetened condensed milk or the microorganisms may also enter to the unsweetened evaporated milk cans through defective seems during cooling or during passage along the wet and contaminated tracks ways Mossel (1983).

Also, some spores can survive pasteurization and affect the quality of fluid milk and other processed dairy products.

Neither Coliforms nor anaerobic bacteria could be detected in all examined samples. These results were complied with ES.part 1 and 2 (2005) as it requires negative Coliforms and negative anaerobes; also Ahmed et al. (1988) couldn't detect them. Robinson (2002) stated that Coliforms, may die off with holding, but yeast and moulds may proliferate.

Total Yeast and Mould counts were shown in Table (3) for full cream sweetened condensed and in Table (4) for full cream unsweetened evaporated samples, with means of $1.5 \times 10 \pm 0.53 \times 10$ and $1.4 \times 10 \pm$ $0.43 \times 10 \mathrm{cfu} / \mathrm{g}$, respectively. They were complied with the ES (part 1 and $2,2005)$ with percentages of 60 and $65 \%$, respectively.

Some moulds are capable of producing toxic metabolites known as mycotoxins, such as aflatoxins which are known as carcinogens (Massey et al., 1995; Markaki and Melissari, 1997).

Generally, concentrated milks are considered as favorable media for the growth of a wide range of environmental contaminants. Canned full 
cream sweetened condensed milk with its high sugar content may swell occasionally owing to the growth of yeasts (Tudor and Board, 1993). Moulds may contaminate the product between the pasteurizer and the canclosing machine through a defective seal or pinhole or the contamination can arise from filling equipment and non- sterile cans. Moreover, moulds may grow over an extremely wide range of temperature, therefore, they can be present on practically all food at almost any temperature under which foods are hold. The sugar is normally an unimportant source of microorganisms, but under unfavorable conditions, it may be contaminated with mold spores, osmophilic yeasts, or bacteria that will produce acid and gas.

Moulds most likely to be present are Aspergillus and Penicillium (Milner, 1995). Classification was done for the mould isolates. The results were in Table (5), revealed the presence of Alternaria alternaria, Aspergillus flavus, Aspergillus fumigates, Aspergillus niger, Aspergillus terreus, Penicillium spp. in full cream sweetened condensed milk samples in percentages of $5,8.33,5,6.67,8.33$ and $6.67 \%$, respectively. While in full cream unsweetened evaporated milk samples they were found in percentages of 3.3, 6.67, 3.3, 10, 6.67 and 5\%, respectively. Yeasts and moulds are undesirable organisms in most dairy products because they affect flavor and odor Ali et al. (2006).

Equally important is the fact that milk is an excellent source of nutrients for humans, and yet in a different context the same nutrients provide most suitable media for microbial growth and metabolism. Many important pathogens like Salmonella spp. and Listeria monocytogenes will grow in liquid milk or high-moisture milk products; and even if these vegetative forms can be eliminated by pasteurization, the spore-formers may cause problems. It is not surprising, therefore, that the quality evaluation of milk and milks products remains a priority interest for everyone associated with the dairy industry (Foster et al., 1983).

\section{REFRENCES}

Adams, M.S. and Moss, M.O. (2000): Food Microbiology $2^{\text {nd }}$ ed. Royal Society of Chemistry. Thomas Graham House, Science Park, Milton Road Cambridge CB 40 WF, UK.

ADPI, American Dairy Products Institute (2000): Evaporated milk. Utilization and production trends. Chicago.

Ahmed, A.A-H.; El-Bassiony, T.A. and Moustafa, M.K. (1988): Microbial evaluation of condensed milk. Assuit Vet. Med. J. 20: 98-102. 
Ali, Manal M.; Salem, Ghada S.E. and Ouf, Gehan M. (2006): Some microbial studies on processed cheddar cheese in local markets. Alexandria. J. Vet. Med. Sci, 24 (1): 49-55.

AOAC, Association of Official Analytical Chemists (1994): Official Methods of Analysis, $15^{\text {th }}$ ed. AOAC, Benjamin Franklin Station, Washington, D.C.USA.

APHA, American Public Health Association (1992): Standards Methods for the Examination of Dairy Products, $16^{\text {th }}$ ed., Washington, D.C. USA.

Arora, K.L. (1987): Quality of sweetened condensed milk manufactured in India. India Dairy -man 39(9)415-417. Dairy Sci. Abst..5(4), 190(1988).

Bailey, W.R. and Scott, E.G. (1998): Diagnostic Microbiology. A Text Book for the Isolation and Identification of Pathogenic Microorganisms. The C.V. Mosby Company Saint Louis.

Barnnett, H.L. and Hunter, B.B. (1972): Illustrated Genera of Imperfect Fungi. $2^{\text {nd }}$ ed., Burgess Publishing Company.

Buttriss, J. (1997): The significance of sodium chloride in studies of Staphylococci. J. Bacteriol., 50: 201-203.

Clark, Stephanie; Costello, Michael; Drake, Maryanne and Body felt, Floyd (2009): The Sensory Evaluation of Dairy Products, Second edition, Library of Congress Control Number: 2008936131.

Clark, W.S. (2000): Evaporated milk. In: Francis, Ed. Wiley Encyclopedia of Food Science and Technology. $2^{\text {nd }}$ Ed. New York: Wiley, pp: 661-662.

Cockburan, W.C. and Vernon, E. (1956): Food poisoning in England and Wales, 1955. Food poisoning of all types. Dairy Sci. Abst. 19: 246 (1957).

Cruickshank, R.; Duguid, J.P.; Marmion, B.P. and Swain, R.H.A. (1975): Medical Microbiology. $12^{\text {th }}$ ed., Vol. II. Page, 417. Churcgill Livingstone, London.

Curran, H.R. and Evans, F.R. (1945): Heat inactivation inducing germination in the spores of the thermotolerant and thermophilic aerobic bacteria. J Bacteriol 49:335 (Applied Dairy Mic.)

Davis, P. (1970): The Chemical Analysis of Foods. $7^{\text {th }}$ ed., Edinburgh, London and New York.

Egyptian Standards (2005): 1830-1; $2 / 2005$. Arab Republic of Egypt. Egyptian Organization for Standardization and Quality Control

FDA (Food and Drug Administration) (2006): 21 CFR, Part 133.169 to 133.180. Food and Drug Administration. Washington, D.C.:Dept. of Health and Human Services. 
Foster, G.M.; Nelson, F.E.; Speck, M.L.; Doetsch, R.N. and Olson, J.C. (1983): Dairy Microbiology. MacMillan \& Colt., London.

Garcia, F.R. (1959): Microbiological control of the manufacture of condensed milk. Dairy Sci. Abst. 24, 256(1962), 2005.

Hui, YH. (1993): Dairy Science and Technology Handbook. vol. 1 Principles and properties. Cambridge- CBI - IHZ - VK - VCH Publishers (UKS Ltd). Chapter 1 Dairy Chemistry and Physics.

Markaki, P. and Melissari, E. (1997): Occurrence of Aflatoxin M1 in commercial pasteurized milk determined with ELISA and HPLC. Food Addit,Contam.5: 451-456.

Massey, T.E.; Stewart, R.K.; Daniel, J.M. and Ling, L. (1995): Biochemimammalian susceptibility to Aflatoxin B1 carcinogenicity. Proceed. Soc. Exp. Med. 208: 313-227.

Milner, J. (1995): Microbiology Handbook. Leatherhead Food RA.Randalls Road, Leather. Head. SurreyKT227RY. Ministry of Health and family welf.

Mossel, D.A.A. (1983): Essentials and Perspectives of the Microbial Ecology of Foods. Eds, T.A.Roberts and F.A.Skinner, London, Academic Press.

Ndprc (2009): National Dairy Products Research Centre. Internet Search about Concentrated milks.

Raper, R.K.B and Fennel, D.I. (1965): The genus Aspergillus. Williams and Wilkins,

Baltimore, Cited after Khalil, R. (1995): M.V.Sc.Thesis, Fac. Vet. Med., Alexandria. Univ. Egypt.

Robinson, R.K. (1990): Dairy Microbiology Vol. 1,2 $2^{\text {nd }}$ ed. The Microbiology of Milk. Elsevier Applied Science, London and New York.

Robinson, R.K. (2002): Dairy Microbiology Handbook, $3^{\text {rd }}$ ed, WileyInterscience, Inc.

Sallam, S.S. (1979): Microbiological investigation of powder and condensed milk. M.V.Sc. Thesis Fac. Vet. Med., Cairo Univ., Egypt.

Samson, R.A.; E.S.; Frisvad, J.C. and Filtenborge, O. (1995): Introduction to Food borne Fungi. $4^{\text {th }}$ ed: Controlburean voor scimmelcultures, Baarn Delft, Printed by Ponsen\&Looyen, Wageningen, The Netherlands.

Tudor, E.A. and Board, R.G. (1993): Food spoilage-yeast. The yeasts. Vol. 5; Yeast Technology. Eds, A.H. Rose\& J.S. Harrison. $2^{\text {nd }}$ ed. London: Academic Press: 435-516. 
USPHS, U.S Public Health Service (1997): Grade A Pasteurized Milk Ordinance. Publication No. 229. Washington, DC: U.S. Department of Health and Human Services, Public Health Service Food and Drug Administration Warren S Clark w.s.; Jr: Concentrated and Dry Milks and Whey. Applied Dairy Microbiology, American Dairy Products Institute. Chicago, Illinois.

Varnam, A.H. and Sutherland, J.P. (1994): Milk and Milk Products. Technology, Chemistry and Microbiology. Chapman and Hall. London.

Zycha, H.; Siepmann, R. and Linnemann, G. (1969): Mucorales, eine Beschreibung aller Gattungen und Arten dieser Pilzgruppe. D. 3301 Lehre J. Gramer. 
Assiut Vet. Med. J. Vol. 57 No. 129 April 2011 
Assiut Vet. Med. J. Vol. 57 No. 129 April 2011 